\title{
Influence of Copper Content of the Base Steel on the Corrosion Behavior of Nickel-coated Steel Sheets
}

\author{
Tomonari OHGA, Toshinori MIZUGUCHI') and Yashichi OYAGI')
}

Surface Treatment Laboratory, Steel Research Laboratory, Nippon Steel Corporation, Shintomi, Futtsu, Chiba-ken, 293 Japan. 1) I/N Kote Quality, I/N Kote, 30755 Edison Road, 1 Vision Drive, New Carlisle, IN 46552-9728, USA.

2) Technical Department, Ishikawa Metal Finishing Co. Ltd., Akasaka-kaigan, Kokurakita-ku, Kitakyushu, Fukuoka-ken, 802 Japan.

(Received on December 13, 1996; accepted in final form on April 11, 1997)

\begin{abstract}
Influence of copper content in a base steel on corrosion resistance of a nickel-coated steel sheet in solutions as strongly corrosive high-acid beverage has been studied, and the following facts were revealed:

Copper addition to the base steel greatly improves the corrosion resistance of the nickel-coated steel sheet in the citric acid and sodium chloride solution. This improvement is resulted from a reduction in the couple current between the nickel and the base steel in the pinholes formed in the nickel coating layer. The reduction in the couple current is considered to arise from shifting corrosion potential of the copper-added steel to the noble direction and increasing in anodic polarization.

The enrichment of copper on the corroded steel surface is considered to bring about great changes in electrochemical properties. The decrease in the couple current between the nickel and the base steel is also obtained under the variation of an area ratio of anode to cathode.

Copper addition to the base steel also gives high corrosion resistance to the nickel-coated steel sheet in the simulated beverages, such as those containing citric acid, citric acid and sodium chloride, malic acid and, lactic acid except containing phosphoric acid.
\end{abstract}

KEY WORDS: nickel-coated steel sheet; welded can; copper-added steel; corrosion resistance.

\section{Background}

Nickel-coated steel sheet is widely used as the material for welded cans. ${ }^{1)}$ However, it is not suited for strongly corrosive high-acid beverages because of its insufficient corrosion resistance.

A large number of studies have been made about the relationship between the chemical compositions of steels and corrosion resistance, ${ }^{2-14)}$ and many of them have revealed the effects of constituents on enhancement of the corrosion resistance of steel sheet per se.

Some studies have also been made about the chemical compositions of the base steels that improve the characteristics and the performance of coated steel sheets. They include a study on the use of steel containing low chromium concentration for the improvement of the corrosion resistance of aluminum-coated steel sheet. ${ }^{15}$ ) For improvement of the corrosion resistance of materials for containers, studies have been also made on the application of nickel diffusion to tinplate ${ }^{16)}$ and the use of steel containing low chromium content as the base steel of the tinplate. ${ }^{17)}$

However, no study has been reported about the chemical composition of the base steel for the improvement of the corrosion resistance of the nickel-coated steel sheet.

This paper discusses the improvement of corrosion resistance of nickel-coated steel sheet in simulated beverages by copper addition to the base steel.

\section{Experimental}

\subsection{Test Specimens}

Table 1 shows chemical compositions of base steels. Six steels containing fixed percentages of carbon, silicon, manganese, phosphorus, sulfur, aluminum and nitrogen as base constituents had different contents of copper of $0,0.04,0.09,0.13,0.18$ and $0.28 \mathrm{wt} \%$.

The six different steels were hot-rolled, pickled, cold-rolled, annealed and skin-pass-rolled under ordinary conditions to make into the base steels for nickel coating.

Table 1. Chemical compositions of base steel. (wt\%)

\begin{tabular}{|c|c|c|c|c|c|c|c|c|}
\hline$N_{0}$ & $C$ & $S i$ & $H n$ & $P$ & $S$ & $A I$ & $N$ & $C_{u}$ \\
\hline 1 & 0.050 & 0.010 & 0.250 & 0.009 & 0.010 & 0.036 & 0.003 & 0.00 \\
\hline 2 & 0.050 & 0.010 & 0.250 & 0.009 & 0.010 & 0.036 & 0.003 & 0.04 \\
\hline 3 & 0.050 & 0.010 & 0.250 & 0.009 & 0.010 & 0.036 & 0.003 & 0.09 \\
\hline 4 & 0.050 & 0.010 & 0.250 & 0.009 & 0.010 & 0.036 & 0.003 & 0.13 \\
\hline 5 & 0.050 & 0.010 & 0.250 & 0.009 & 0.010 & 0.036 & 0.003 & 0.18 \\
\hline 6 & 0.050 & 0.010 & 0.250 & 0.009 & 0.010 & 0.036 & 0.003 & 0.28 \\
\hline
\end{tabular}




\subsection{Nickel-coating and Chromate Treatment Conditions}

The steels were electrolytically degreased in a $5 \mathrm{wt} \%$ solution of sodium hydroxide at $70^{\circ} \mathrm{C}$ and then electrolytically pickled in an aqueous solution containing $10 \mathrm{wt} \%$ sulfuric acid at room temperature. Nickel coating was produced on the steel in a Watt bath to a coating weight of $500 \mathrm{mg} / \mathrm{m}^{2}$. The Watt bath contained $240 \mathrm{~g}$ of nickel sulfate, $35 \mathrm{~g}$ of nickel chloride and $30 \mathrm{~g}$ of boric acid in one liter of the solution and was kept at $50^{\circ} \mathrm{C}$. The nickel-coated specimens were coated with a film of chromate containing 5 to $6 \mathrm{mg} / \mathrm{m}^{2}$ of chromium in total. The chromate coating weight was controlled by current density. The chromate treatment was carried out in a bath containing $60 \mathrm{~g}$ of chromic acid and $0.4 \mathrm{~g}$ of sulfate ion in one liter of the solution and kept at $45^{\circ} \mathrm{C}$.

\subsection{Dissolved Iron Value Test}

To confirm the corrosion resistance of the nickelcoated copper-added steel sheet, an iron dissolution test was made. The cut edges of the nickel-coated test specimens were sealed and the specimen was immersed in an aqueous solution containing $1.5 \mathrm{wt} \%$ of each of citric acid and sodium chloride, that was deaerated with nitrogen gas, adjusted to $\mathrm{pH} 2.8$ by sodium hydroxide, and kept at $27^{\circ} \mathrm{C}$ for $24 \mathrm{~h}$. The amount of iron dissolved into the solution was measured by inductivity coupled plasma spectrometry (ICP).

\subsection{Electrochemical Measurement}

A typical corrosive solution was an aqueous solution containing $1.5 \mathrm{wt} \%$ of each of citric acid and sodium chloride. The solution was deaerated with nitrogen gas, and was adjusted to $\mathrm{pH} 2.8$. To grasp applicability of the coated steel to the practical beverage can, aqueous solutions containing $0.5 \mathrm{wt} \%$ of phosphoric acid, citric acid, malic acid, and lactic acid were used as simulated beverages. The solutions were deaerated with nitrogen gas, and were adjusted to $\mathrm{pH} 2.8$ by sodium hydroxide. Temperature of the solution was $27^{\circ} \mathrm{C}$.

The corrosion potentials of a nickel, whose purity is $99.99 \mathrm{wt} \%$, and the steel sheets over an area of 10 by $10 \mathrm{~mm}$ (indicated as $E_{\text {corr }}$ in the figures) were measured in the test solution by using a saturated calomel electrode (S.C.E.) as a reference electrode.

The corrosion rate of the base steel sheet (indicated as $i_{\text {corr }}$ in the figures) was determined by immersing the specimen having a size of 5 by $50 \mathrm{~mm}$ in the test solution. Weight reduction of the specimen after $24 \mathrm{~h}$ was measured.

The couple current between the nickel and the steel sheet (indicated as $i_{\text {couple }}$ in the figures) was determined in the test solution by using an N-HT-5M zero resistance current meter of Nichia Keiki Co., Ltd. The dimension of the specimens was 10 by $10 \mathrm{~mm}$, and the area ratio between the nickel and the steel sheets was varied to $1: 1$, $10: 1,50: 1$ and $100: 1$ in the case of discussing the effect of the area ratio on the couple current.

The polarization characteristics of the copper-added steel was determined in the test solution by the potentiokinetic method at $1 \mathrm{mV} / \mathrm{sec}$, using a CW-E2 potentiostat of Nichia Keiki Co., Ltd. The specimens had a dimension of 10 by $10 \mathrm{~mm}$.

\subsection{Analysis of Surface Quality of the Steel Sheet}

To determine the surface quality of the copper-added steel, its corroded surface was examined by a GDS (Glow Discharge Spectrometer) method under a voltage of $600 \mathrm{~V}$, a current of $20 \mathrm{~mA}$, and an argon flowing rate of $230 \mathrm{ml} / \mathrm{min}$.

\section{Results and Discussion}

\subsection{Dissolved Iron Value Test}

To determine the corrosion resistance of the nickelcoated steel sheet made from the copper-added steel, the iron dissolution value test was made. Figure 1 shows the amount of iron dissolved in the solution measured by the ICP and converted to the values per unit area. As can be seen, the amount of iron dissolved from the nickel-coated steel sheets decreased with an increase in copper content. Assuming that all the specimens have almost the equal total area of pinholes in the layer of nickel coating, addition of copper to the steels are proved to increase the corrosion resistance of the nickel-coated steel sheets because the dissolution of iron occurs through the pinholes in the layer of nickel coating.

\subsection{Couple Current and Corrosion Rate}

The dissolution of iron occurs from the nickel-coated steel sheets through the pinholes in the layer of nickel coating. Two reactions are considered to occur in the pinholes in the nickel coating layer; one is a reaction in which iron dissolves from the steel sheet that becomes the anode when the nickel coating is nobler than the steel. The other is a reaction in which the steel sheet itself dissolves in the pinholes without any help from nickel.

To clarify which of the two reactions governs the iron dissolution, the couple current and the corrosion rate of the base steel were determined in the test solution.

Figure 2 shows the couple currents between the nickel and the steels containing different contents of copper obtained after immersion for 9 and $24 \mathrm{~h}$. Obviously, the couple current decreases considerably with an increase in copper content. Figure 3 shows the corrosion rates of the steels as a function of copper content. Addition of copper to the steel greatly reduces the rate of corrosion

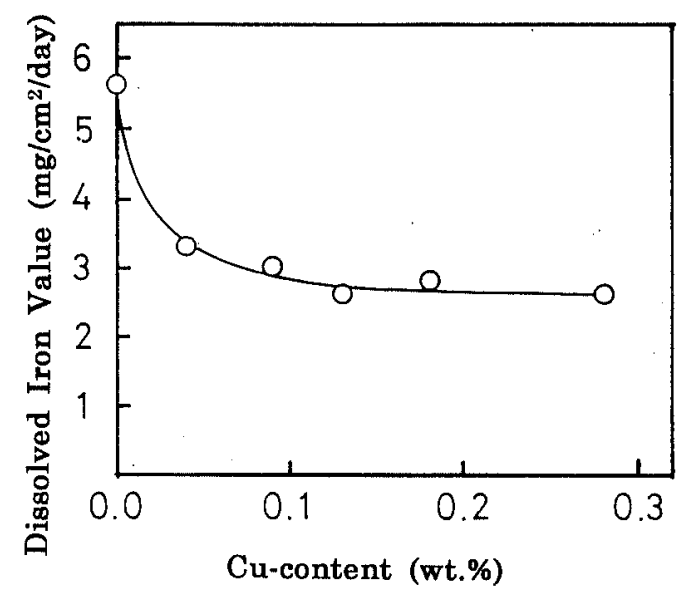

Fig. 1. Dissolved iron value of nickel coated steel sheets. 


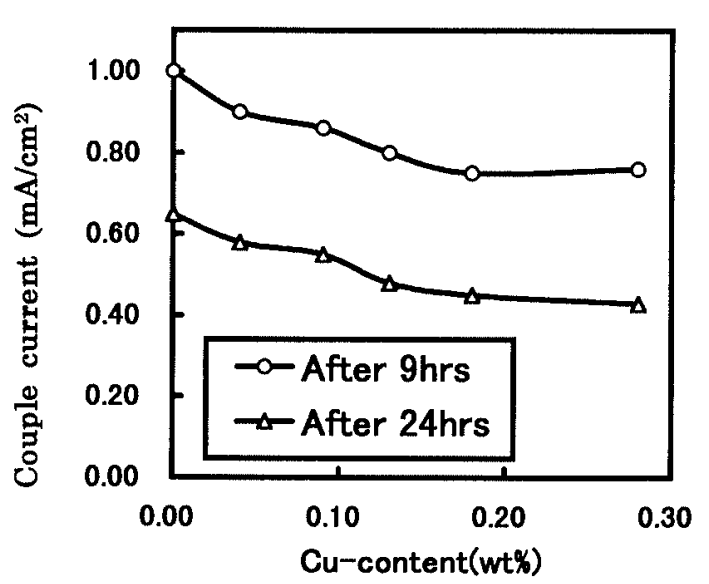

Fig. 2. Effect of copper content on couple current.

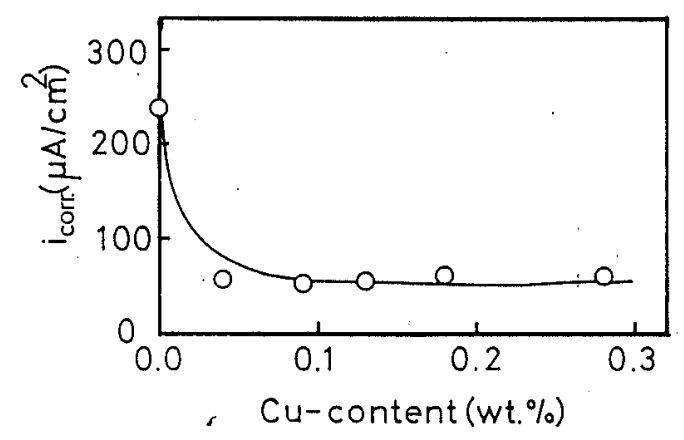

Fig. 3. Relationship between copper content and $i_{\text {corr }}$.

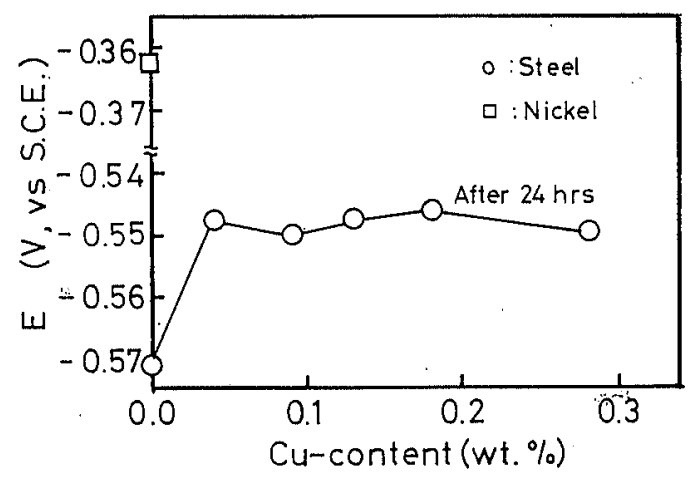

Fig. 4. Effect of copper content on $E_{\text {corr }}$ :

rate.

As may be seen from Figs. 2 and 3, the couple current is much greater than the corrosion rate. This means that the iron dissolution through the pinholes of the nickelcoated steel sheets is mainly due to the galvanic corrosion resulted from the coupling of the steel sheet and the nickel coating.

\subsection{Corrosion Potential and Polarization Characteris- tics}

The improvement in corrosion resistance of the nickelcoated and copper-added steels is due to the decrease in the couple current between the nickel and the steel sheet. The reason why this decrease in couple current occurs was studied from an electrochemical standpoint. The corrosion potential and the polarization characteristics were determined in the test solution.

Figure 4 shows the corrosion potentials of the base steel measured after the immersion in $24 \mathrm{~h}$ as a function

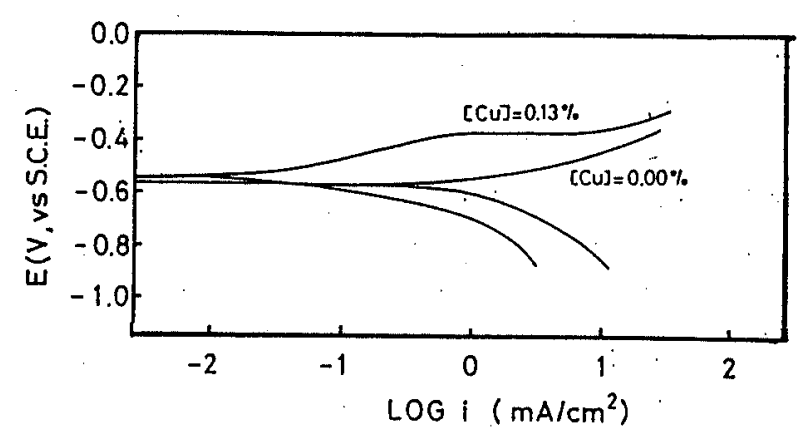

Fig. 5. Polarization curves of the steel sheets with and without copper.

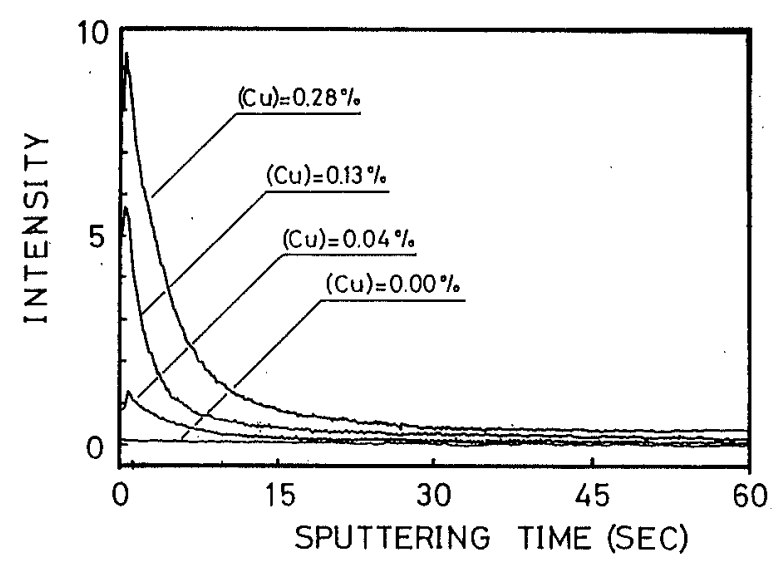

Fig. 6. Depth profiles of copper in the steel sheets.

of copper content. Obviously, the addition of copper shifts the corrosion potential of the steel sheet to the noble direction and makes it closer to that of nickel. Figure 5 shows polarization curves of the steel without containing copper and one containing $0.13 \mathrm{wt} \%$ copper. Obviously, the copper-added steel exhibits greater cathodic and anodic polarization than the steel without copper addition. Increase in anodic polarization is particularly great.

Thus, the following reactions are considered to take place in the pinholes of the nickel-coated layer and on the nickel-coated layer:

$$
\begin{aligned}
& \text { Anodic reaction: } \mathrm{Fe} \rightarrow \mathrm{Fe}^{2+}+2 \mathrm{e}^{-} \\
& \text {Cathodic reaction: } 2 \mathrm{H}^{+}+2 \mathrm{e}^{-} \rightarrow \mathrm{H}_{2}
\end{aligned}
$$

Hence, addition of copper is considered to reduce the rate of the above reactions by narrowing down the difference in corrosion potential between the steel sheet and the nickel and by increasing the anodic polarization of steel sheet.

\subsection{Surface Quality of Copper-added Steel}

As stated above, the copper-added steel exhibits greater anodic polarization and the shifting of corrosion potential to the noble side. Figure 6 shows depth profiles of copper in the copper-added steel sheets determined by the use of the GDS to show its surface quality. The test specimens were those used in the measurement of couple current over a period of $24 \mathrm{~h}$. As can be seen in Fig. 6, copper enrichment is observed on the surface of the steel sheet. This tendency is more pronounced in the steels containing greater amounts of copper. 
This enrichment of copper is considered to be due to the precipitation of copper salt on the surface of steel sheet. ${ }^{18-20)}$ In the pinholes in the nickel-coating layer on the copper-added steel sheets, anodic reaction is the process of iron dissolution. The enrichment of copper on the surface narrows down the potential difference between the steel and the nickel, and thereby, the anodic polarization of iron increases and the dissolution of iron reduces.

\subsection{Area Ratio between Anode and Cathode}

The area of the cathodic region that is the nickelcoating layer is much greater than that of the anodic region of the pinholes in the nickel-coating layer, where the steel is exposed. To determine the effect of the area ratio on the corrosion resistance, the couple current was measured by varying the area ratio between the nickel coating and the steel sheet.

Figure 7 shows the relationship between the logarithm of the area ratio between the nickel coating and the steel sheet and that of the couple current. The solid marks indicate the copper-added steel and the hollow marks indicate the copper-free steel. Here, $i_{\mathrm{Fe}}$ indicates the anodic current density, $S_{\mathrm{Fe}}$ and $S_{\mathrm{Ni}}$ indicate the area of steel electrode and nickel electrode.

As shown in Fig. 7, there is a linear relationship between the logarithm of the area ratio and that of the couple current. The slope of this line is expressed as $-\beta_{\mathrm{Ni}, \mathrm{c}} /\left(\beta_{\mathrm{Ni}, \mathrm{c}}+\beta_{\mathrm{Fe}, \mathrm{a}}\right)$, see Appendix, where $\beta_{\mathrm{Ni}, \mathrm{c}}=2.3 R T /$ $\alpha_{\mathrm{Ni}, \mathrm{c}} n F, \quad \beta_{\mathrm{Fe}, \mathrm{a}}=2.3 R T / \alpha_{\mathrm{Fe}, \mathrm{a}} n F, \quad R=$ gas constant, $\quad T=$ absolute temperature, $\alpha_{\mathrm{Ni}, \mathrm{c}}=$ symmetry factor of cathodic reaction, $\alpha_{\mathrm{Fe}, \mathrm{a}}=$ symmetry factor of anodic reaction, $n=$ charge-transfer number and $F=$ Faraday constant

Figure 7 shows that the copper-added steel has less anodic current and greater corrosion resistance than copper-free steel. Therefore, copper-added steel exhibits good corrosion resistance even where the area of the anodic region, such as the pinholes in the coating layer, is much smaller than the area of the cathodic region, that is, anodic current density is high.

\subsection{Results of Study in Different Corrosive Solutions}

The model corrosive solution discussed so far was the

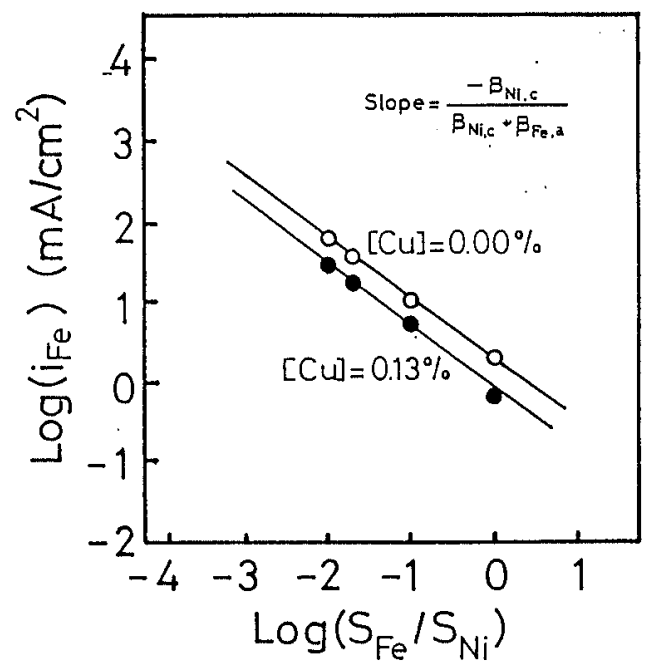

Fig. 7. Relationship between $\mathrm{Fe} / \mathrm{Ni}$ area ratio and $i_{\mathrm{Fe}}$ aqueous solution containing $1.5 \mathrm{wt} \%$ of each of citric acid and sodium chloride. To determine the corrosion resistance of the nickel-coated copper-added steel in various corrosive solutions, the couple current, corrosion potential and corrosion rate were measured in the solutions containing $0.5 \mathrm{wt} \%$ of phosphoric, citric, malic and lactic acid, with the $\mathrm{pH}$ adjusted to 2.8 by sodium hydroxide. All solutions were deaerated with nitrogen gas and kept at $28^{\circ} \mathrm{C}$.

Figure 8 shows the couple currents between the nickel and the steel sheets measured in the individual corrosive solutions. The effect of copper addition to the steel on the reduction of the couple current was observed in all the solutions except the solution of phosphoric acid. Namely, the effect was observed in the aqueous solutions of citric acid, citric acid and sodium chloride, malic acid, and lactic acid.

Figure 9 shows the corrosion potentials in the individual corrosive solutions. The copper addition to the steel caused the corrosion potential closer to that of the nickel in all the corrosive solutions but the solution of phosphoric acid. This is one reason why the decrease in couple currents between the nickel and the steel in the various corrosive solutions.

In addition, Fig. 10 shows the corrosion rates of the base steels in the various corrosive solutions. The effect of copper addition on the reduction of corrosion rate was remarkably observed in all the corrosive solutions but the solution of phosphoric acid. Though the contribution of corrosion rate toward the corrosion resistance of nickel coated steel is not so large, it is clear that the effect of copper addition to the steel on the reduction of corrosion rate is recognized.

In summary, Figs. 8, 9, and 10 indicate that the use

\begin{tabular}{|c|c|c|c|}
\hline \multirow[b]{2}{*}{ Corrosion solutions } & \multirow{2}{*}{$\mathrm{pH}$} & \multicolumn{2}{|c|}{$i_{\text {couple }}\left(\mathrm{mA} / \mathrm{cm}^{2}\right)$} \\
\hline & & 10 & 2 \\
\hline $0.5 \%$ Phosphoric acid & 2.8 & 0 & \\
\hline $0.5 \%$ Citric acid & 2.8 & - 0 & \\
\hline $\begin{array}{l}1.5 \% \text { Citric acid } \\
+1.5 \% \mathrm{NaCl} \\
\end{array}$ & 2.8 & $\bullet$ & 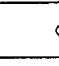 \\
\hline $0.5 \%$ Malic acid & 2.8 & $\because 0$ & \\
\hline $0.5 \%$ Lactic acid & 2.8 & - & \\
\hline
\end{tabular}

Fig. 8. Relationship between $i_{\text {couple }}$ and kinds of solutions. $\mathrm{O}:[\mathrm{Cu}]=0.00 \%$

: $[\mathrm{Cu}]=0.13 \%$

\begin{tabular}{|c|c|c|c|}
\hline Corrosion solutions & $\mathrm{pH}$ & $\begin{array}{r}E_{\text {corr. }} \text { (V, vs S.C } \\
-0.8-0.7-0.6 \quad-0\end{array}$ & -0.3 \\
\hline $0.5 \%$ Phosphoric acid & 2.8 & $\bullet$ & 口 \\
\hline $0.5 \%$ Citric acid & 2.8 & $\circ:$ & D \\
\hline $\begin{array}{c}1.5 \% \text { Citric acid } \\
+1.5 \% \mathrm{NaCl}\end{array}$ & 2.8 & $\circ$ & $\square$ \\
\hline $0.5 \%$ Malic acid & 2.8 & $\circ \cdot$ & - \\
\hline $0.5 \%$ Lactic acid & 2.8 & $\circ \cdot$ & - \\
\hline
\end{tabular}

Fig. 9. Relationship between $E_{\text {corr }}$ and kinds of solutions. O: Steel-1 $([\mathrm{Cu}]=0.00 \%)$

: Steel-2 $([\mathrm{Cu}]=0.13 \%)$ $\square$ : Nickel 


\begin{tabular}{|c|c|c|c|c|}
\hline \multirow[b]{2}{*}{ Corrosion solutions } & \multirow[b]{2}{*}{$\mathrm{pH}$} & \multicolumn{3}{|c|}{$\mathrm{i}_{\text {corr. }}\left(\mu \mathrm{A} / \mathrm{cm}^{2}\right)$} \\
\hline & & 50 & 100 & 150 \\
\hline $0.5 \%$ Phosphoric acid & 2.8 & $\infty$ & & \\
\hline $0.5 \%$ Citric acid & 2.8 & - & $\circ$ & \\
\hline $\begin{array}{l}1.5 \% \text { Citric acid } \\
+1.5 \% \mathrm{NaCl} \\
\end{array}$ & 2.8 & - & & $\circ$ \\
\hline $0.5 \%$ Malic acid & 2.8 & - & $\circ$ & \\
\hline $0.5 \%$ Lactic acid & 28 & - & o & \\
\hline
\end{tabular}

Fig. 10. Relationship between $i_{\text {corr }}$ and kinds of solutions. $\mathrm{O}:[\mathrm{Cu}]=0.00 \%$

: $[\mathrm{Cu}]=0.13 \%$

of copper-added steel was proved to be effective in the improvement of the corrosion resistance of the nickelcoated steel sheets. Conceivably, the nickel-coated steel sheets made from the copper-added steel have great corrosion resistance to beverages containing citric acid, citric acid and sodium chloride, malic acid, and lactic acid. An exception is the beverage containing phosphate acid.

\section{Conclusions}

The studies revealed the following facts:

(1) Copper addition to the base steel causes the improvement of the corrosion resistance of the nickelcoated steel sheet.

(2) The improvement of corrosion resistance of the material is due to a reduction in the couple current between the nickel and the steel sheet in the pinholes in the nickel-coating layer.

(3) The reduction in the couple current is considered to be resulted from the shift of the corrosion potential to the noble side and from the increase in anodic polarization.

(4) The enrichment of copper observed on the corroded surface of the copper-added steel is considered to greatly change the electrochemical properties.

(5) The decrease in the couple current between the nickel and the steel was obtained even when the area ratio of the anodic to the cathodic region was varied.

(6) The use of copper-added steel is expected to greatly improve the corrosion resistance in beverages containing citric acid, citric acid and sodium chloride, malic acid, and lactic acid. An exception is the beverage containing phosphoric acid.

\section{REFERENCES}

1) S. Higuchi, T. Ohga, N. Miake, K. Yamaguchi and Y. Ohyagi: J. Met. Finish. Soc. Jpn., 38 (1987), 16.

2) Corrosion and Corrosion Control, 2nd Ed., ed. by H. H. Uhlig, Sangyo Tosho, Tokyo, (1980), 110.

3) T. Shibata: J. Soc. Mater. Sci. Jpn., 41 (1992), 1321.

4) S. Maeda: Corros. Eng. (Jpn.), 32 (1983), 37.

5) H. Okada and H. Shimade: Tetsu-to-Hagané, 60 (1974), 540.

6) C. P. Larrabee and S. K. Cobwrn: Proc. Ist Int. Cong. on Metallic Corrosion, NACE, Houston, Texas, (1961), 276.

7) Corrosion, Causes and Prevention, 3rd Ed. McGraw-Hill, New York, (1951), 106.

8) E. Williams and M. E. Komp: Corrosion, 21 (1965), 9.

9) J. A. Shropshire: J. Electrochem. Soc., 107 (1960), 740.
10) J. Horvath and L. Hack: Corros. Sci., 5 (1969), 525.

11) C. P. Larrabee: Corrosion, 14 (1958), 501.

12) C. Kato, Y. Otoguro and S. Kado: Corros. Eng. (Jpn.), 23 (1974), 425.

13) Kinzoku no Hushoku Sonshou to Boshoku Gijutsu, ed. by M. Kowaka, Agune Shohusha, Tokyo, (1995).

14) H. R. Copson: J. Iron Steel Inst., 201 (1963), 3.

15) S. Higuchi and K. Asakawa: Tetsu-to-Hagané, 78 (1992), 1569.

16) K. Mochizuki, H. Nakakohji, H. Ogata, T. Ichida and T. Irie: Kawasaki Steel Giho, 16 (1984), 314.

17) S. Higuchi and T. Katayama: Tetsu-to-Hagané, 79 (1993), 961.

18) H. J. Cleary and N. D. Green: Corros. Sci., 7 (1967), 827.

19) G. Wranglen: Corros. Sci., 9 (1969), 585.

20) C. Kato, Y. Otoguro and S. Kado: Tetsu-to-Hagané, 63 (1977), 130.

\section{Appendix}

In the galvanic cell between the nickel and the steel, the anodic and the cathodic current are shown following equations.

$$
\begin{aligned}
& i_{\mathrm{Fe}}=i_{0, \mathrm{Fe}} \exp \left(\alpha_{\mathrm{Fe}, \mathrm{a}} n F\left(E_{\text {couple }}-E_{\text {corr }, \mathrm{Fe}}\right) / R T\right) \ldots \ldots(\mathrm{A}-1) \\
& i_{\mathrm{Ni}}=i_{0, \mathrm{H}_{2}} \exp \left(\alpha_{\mathrm{Ni}, \mathrm{c}} n F\left(E_{\text {corr }, \mathrm{Ni}}-E_{\text {couple }}\right) / R T\right) \ldots \ldots(\mathrm{A}-2)
\end{aligned}
$$

where $i_{\mathrm{Fe}}$ : anodic current of the iron dissolution, $i_{\mathrm{Ni}}$ : cathodic current of the hydrogen evolution, on the nickel coating layer, $i_{0, \mathrm{Fe}}$ : exchange current density of the iron, $i_{0, \mathrm{H}_{2}}$ : exchange current density of the hydrogen,

$\alpha_{\mathrm{Fe}, \mathrm{a}}: \quad$ symmetry factor of the anodic reaction,

$\alpha_{\mathrm{Ni}, \mathrm{c}}: \quad$ symmetry factor of the cathodic reaction,

$n: \quad$ charge-transfer number,

$E_{\text {couple }}:$ couple potential between the nickel and the steel,

$E_{\text {corr, } \mathrm{Fe}}:$ corrosion potential of the steel,

$E_{\text {corr }, \mathrm{Ni}}$ : corrosion potential of the nickel,

$R: \quad$ gas constant,

$T: \quad$ absolute temperature,

$F$ : Faraday constant.

From Eq. (A-1)

$$
E_{\text {couple }}-E_{\text {corr }, \mathrm{Fc}}=\beta_{\mathrm{Fe}, \mathrm{a}} \log \left(i_{\mathrm{Fe}} / i_{0, \mathrm{Fe}}\right)
$$

where $\beta_{\mathrm{Fe}, \mathrm{a}}=2.3 R T / \alpha_{\mathrm{Fe}, \mathrm{a}} n F$.

From Eq. (A-2)

$$
E_{\text {corr }, \mathrm{Ni}}-E_{\text {couple }}=\beta_{\mathrm{Ni}, \mathrm{c}} \log \left(i_{\mathrm{Ni}} / i_{0, \mathrm{H}_{2}}\right)
$$

where $\beta_{\mathrm{Ni}, \mathrm{c}}=2.3 R T / \alpha_{\mathrm{Ni}, \mathrm{c}} n F$.

By combining Eqs. (A-3) and (A-4), the information about the corrosion potential difference is expressed as the following equation.

$$
E_{\mathrm{corr}, \mathrm{Ni}}-E_{\mathrm{corr}, \mathrm{Fe}}=\beta_{\mathrm{Fe}, \mathrm{a}} \log \left(i_{\mathrm{Fe}} / i_{0, \mathrm{Fe}}\right)+\beta_{\mathrm{Ni}, \mathrm{c}} \log \left(i_{\mathrm{Ni}} / i_{0, \mathrm{H}_{2}}\right)
$$

In the pinhole of the nickel coating layer, the anodic and cathodic currents balance holds the following equation.

$$
i_{\mathrm{Fe}} \cdot S_{\mathrm{Fe}}=i_{\mathrm{Ni}} \cdot S_{\mathrm{Ni}}
$$

where $S_{\mathrm{Fe}}$ : the area of the iron electrode, $S_{\mathrm{Ni}}$ : the area of the nickel electrode. 
Substituting Eq. (A-6) into (A-5), the following equation can be derived.

$$
\begin{aligned}
& E_{\mathrm{corr}, \mathrm{Ni}}-E_{\mathrm{corr}, \mathrm{Fe}}=\beta_{\mathrm{Fe}, \mathrm{a}} \log \left(i_{\mathrm{Fe}}\right)-\beta_{\mathrm{Fe}, \mathrm{c}} \log \left(i_{0, \mathrm{Fe}}\right) \\
& \quad+\beta_{\mathrm{Ni}, \mathrm{c}} \log \left(i_{\mathrm{Fe}} \cdot S_{\mathrm{Fe}} / S_{\mathrm{Ni}}\right)-\beta_{\mathrm{Ni}, \mathrm{c}} \log \left(i_{0, \mathrm{H}_{2}}\right) \ldots \ldots .
\end{aligned}
$$

Rearranging the Eq. (A-7),

$$
\begin{aligned}
& \left(\beta_{\mathrm{Ni}, \mathrm{c}}+\beta_{\mathrm{Fe}, \mathrm{a}}\right) \log \left(i_{\mathrm{Fe}}\right)=-\beta_{\mathrm{Ni}, \mathrm{e}} \log \left(S_{\mathrm{Fe}} / S_{\mathrm{Ni}}\right) \\
& \quad+\beta_{\mathrm{Fe}, \mathrm{a}} \log \left(i_{0, \mathrm{Fe}}\right)+\beta_{\mathrm{Ni}, \mathrm{c}} \log \left(i_{0, \mathrm{H}}\right) \\
& \quad+E_{\mathrm{corr}, \mathrm{Ni}}-E_{\mathrm{corr}, \mathrm{Fe}}
\end{aligned}
$$

Finally, the relationship between $i_{\mathrm{Fe}}$ and $S_{\mathrm{Fe}} / S_{\mathrm{Ni}}$ is expressed as the following equation.

$$
\begin{aligned}
& \log \left(i_{\mathrm{Fe}}\right)=\left(-\beta_{\mathrm{Ni}, \mathrm{c}} /\left(\beta_{\mathrm{Ni}, \mathrm{c}}+\beta_{\mathrm{Fe}, \mathrm{a}}\right)\right) \cdot \log \left(S_{\mathrm{Fe}} / S_{\mathrm{Ni}}\right) \\
& +\left(\beta_{\mathrm{Fe}, \mathrm{a}} \log \left(i_{0, \mathrm{Fe}}\right)+\beta_{\mathrm{Ni}, \mathrm{c}} \log \left(i_{0, \mathrm{H}_{2}}\right)\right. \\
& \left.+E_{\text {corr }, \mathrm{Ni}}-E_{\mathrm{corr}, \mathrm{Fe}}\right) /\left(\beta_{\mathrm{Ni}, \mathrm{c}}+\beta_{\mathrm{Fe}, \mathrm{a}}\right)
\end{aligned}
$$

